\title{
Assessment of the biodegradability of polymer based on polyacrylates
}

\author{
(C) Leysan R. Galimzyanova, ${ }^{1}$ Tatiana V. Vdovina, ${ }^{1}{ }^{+}$ \\ Yoldyz V. Kobeleva, ${ }^{1} *$ and Natalia V. Galkina ${ }^{2}$ \\ ${ }^{1}$ Department of Industrial Biotechnology. Kazan National Research Technological University. \\ K. Marx St., 68. Kazan, 420015. The Republic of Tatarstan, Russia. \\ Phone:+7 (939) 394-38-62.E-mail: gl2701@mail.ru \\ ${ }^{2}$ ELTEKH, OOO. St. Petersburg, 50, building 26, 27, office 310. Kazan, 420107. Republic of Tatarstan. \\ Russia.Phone: +7 (917) 278-38-16. E-mail: galkinatasha@yandex.ru
}

*Supervising author; ${ }^{+}$Corresponding author

Keywords: biodegradation, polyacrylates, biodegradable polymeric materials, respiratory activity of microorganisms.

\begin{abstract}
The article is devoted to a comprehensive study of the assessment of biodegradability of polymer based on acrylic acid and its copolymers, used as an impregnation of paper napkins, by microorganisms of soil and activated sludge biocenosis. Experimental studies were carried out with $10 \%, 1 \%, 0.1 \%, 0.01 \%, 0.001 \%$ and $0.0001 \%$ aqueous solutions of polymer based on acrylic acid. The assessment of the biodegradation ability of polyacrylates by microorganisms of soil biocenosis and activated sludge was carried out on the basis of changes in the respiratory activity of microbiocenoses under conditions of introduction into the soil and waste water, respectively, of the analyzed polymer samples based on acrylic acid and its derivatives. Based on the changes in the respiratory activity of microorganisms in the presence of polymers, it was revealed that polyacrylates are biodegradable and can be used by soil microbiocenosis and activated sludge microbiocenosis as a substrate. The results of quantitative counting of microorganisms of activated sludge by the method of limiting dilutions in the process of long-term cultivation in the presence of polymer samples correlate with the results of determining the respiratory activity of microbiocenoses and indicate the possibility of using polyacrylates by microorganisms as a substrate. In the process of experimental studies, it was proved that in the aquatic environment both large respiratory activity of microorganisms at low concentrations of the polymer and a higher inhibitory activity of the polymer at its high concentrations than in the soil are observed. The results indicate the promise of using solutions of polyacrylates as impregnation of paper napkins, since the methods of processing and disposal of used napkins meet the requirements of environmental friendliness.
\end{abstract}

\section{References}

[1] O.V. Babkina, K.V. Alekseenko, V.T. Novikov, and O.K. Kuchina. Specific features of biodegradable polyglycolidelactide synthesis. Butlerov Communications. 2012. Vol.32. No.12. P.31-34. ROI: jbc-02/1232-12-31

[2] A.N. Dautova, V.V. Yanov, E.I. Alexeev, and L.A. Zenitova. Biodegradable polymer composite materials using natural rubber. Butlerov Communications. 2017. Vol.52. No.10. P.56-73. DOI: 10.37952/ROI-jbc$01 / 17-52-10-56$

[3] "Addnano Flash - Water-Soluble polymer", [Electronic resource]. https://www.addnano.ru/vodorastvorimyj-polimer.

[4] P.Yu. Galitskaya, S.Yu. Selivanovskaya, R.H. Gumerova. Testing of waste, soils, materials using living systems: studies.-method.benefit. Kazan: Publishing house of KAZAN state technical University. 2011. 48p. (russian)

[5] A.S. Sirotkin [and others]. Biofiltration of sewage: a textbook. M-in image and science of Russia. National Research Technological University. Kazan: Publishing house of KAZAN state technical University. 2014. 172p. (russian)

[6] E.I. Novoselova. Enzymatic activity of soils in the conditions of oil pollution and its biodiagnostic value. LLC Publishing house "Kamertone". 2009. No.2. P.4-12. (russian)

[7] Y.G. Maksimova, A.A. Gorshkova, V.A. Demakov. "Biodegradation of polyacrylamide soil microflora and imidazolidines strains of bacteria." Bulletin Of Perm University. 2017. No.2. P.200-204. (russian)

[8] P. Vaculik. Chemistry of monomers. Volume 1. Translated from the Czech. Moscow: "Publishing house of foreign literature". 1960. (russian) 